\title{
The genus Zygothrica Wiedemann 1830 (Diptera, Drosophilidae) in Santa Catarina state, southern Brazil: distribution and ecological notes
}

\author{
Jonas da Silva Döge ${ }^{1,3}$, Marco Silva Gottschalk', Luís Eduardo Maestrelli Bizzo², \\ Sabrina Cassimiro Fonseca de Oliveira ${ }^{1}$, Hermes José Schmitz, \\ Vera Lúcia da Silva Valente ${ }^{1}$ \& Paulo Roberto Petersen Hofmann ${ }^{2}$
}

Biota Neotropica v7 (n3) - http://www.biotaneotropica.org.br/v7n3/pt/abstract?article + bn00207032007

\author{
Data Received 12/03/07 \\ Revised 15/07/07 \\ Accepted 01/09/07
}

\author{
${ }^{1}$ Programa de Pós-Graduação em Biologia Animal, Laboratório de Drosophila, \\ Departamento de Genética, Instituto de Biociências Universidade Federal do Rio Grande do Sul-UFRGS, \\ Av. Bento Gonçalves, $n^{\circ}$ 9500, Prédio 43323, Bairro Agronomia, CP 15053, \\ CEP 91501-970, Porto Alegre, RS, Brazil \\ ${ }^{2}$ Laboratório de Drosofilídeos, Departamento de Biologia Celular, Embriologia e Genética, \\ Centro de Ciências Biológicas, Universidade Federal de Santa Catarina - UFSC \\ Campus Universitário, Bairro Trindade, CEP 88036-400, \\ Florianópolis, SC, Brazil, http://www.drosofilideos.ufsc.br/ \\ ${ }^{3}$ Corresponding author: Jonas da Silva Döge, \\ e-mail: jdoge@hotmail.com,http://www.ufrgs.br/zoologia/index.htm
}

\begin{abstract}
Doge, J.S., Gottschalk, M.S., Bizzo, L.E.M., Oliveira, S.C.F., Schmitz, H.J., Valente, V.L.S. \& Hofmann, P.R.P. The genus Zygothrica Wiedemann 1830 (Diptera, Drosophilidae) in Santa Catarina state, southern Brazil: distribution and ecological notes. Biota Neotrop. Sep/Dez 2007 vol. 7, no. 3 http://www.biotaneotropica.org.br/v7n3/pt/abstract?article+bn00207032007. ISSN 1676-0603.

The present paper brings together survey data from nine collection sites in Santa Catarina state, southern Brazil. Samples were obtained during about four years in forested, coastal and urban areas. Flies were attracted by fermented banana baits and captured in traps. Among the species of the genus Zygothrica Wiedemann 1830 collected, Zygothrica apopoeyi Burla 1956, Z. bilineata (Williston 1896), Z. dispar (Wiedemann 1830), Z. lanceolata Burla 1956, Z. nigropleura Grimaldi 1987, and Z. poeyi (Sturtevant 1921) were recorded for the first time in Santa Catarina state and, except for Z. bilineata, also in southern Brazil. Apart from these species, we also collected Zygothrica hypandriata Burla 1956, Z. orbitalis (Sturtevant 1916) (as Z. parilis), Z. prodispar Duda 1925 and Z. vittimaculosa Burla 1956. Except for Z. bilineata and Z. hypandriata, these are the new southernmost records for the geographical distribution of these species. All the collected species were represented by few individuals, probably as a consequence of the collection method, and most of them was captured in winters and springs. Five species were restricted to the more preserved studied site, and most individuals were collected in forest sites. Nevertheless, four species were also captured in urban or xeric environments, indicating a higher tolerance and a wider ecological versatility in this genus as compared to what was previously thought, at least for some species.
\end{abstract}

Keywords: Neotropics, new records, species distribution.

\section{Resumo}

Doge, J.S., Gottschalk, M.S., Bizzo, L.E.M., Oliveira, S.C.F., Schmitz, H.J., Valente, V.L.S. \& Hofmann, P.R.P. O gênero Zygothrica Wiedemann 1830 (Diptera, Drosophilidae) no Estado de Santa Catarina, sul do Brasil: distribuição e notas ecológicas. Biota Neotrop. Sep/Dez 2007 vol. 7, no. 3 http://www.biotaneotropica.org.br/v7n3/pt/abstract?article+bn00207032007. ISSN 1676-0603.

O presente estudo reúne dados de pesquisa de nove locais de coleta no estado de Santa Catarina, sul do Brasil. Foram obtidas amostras durante aproximadamente quatro anos em áreas florestais, litorâneas e urbanas. As moscas foram atraídas através de isca de banana fermentada e capturadas em armadilhas. Dentre as espécies do gênero Zygothrica Wiedemann 1830 coletadas, Zygothrica apopoeyi Burla 1956, Z. bilineata (Williston 1896), Z. dispar (Wiedemann 1830), Z. lanceolata Burla 1956, Z. nigropleura Grimaldi 1987, e Z. poeyi (Sturtevant 1921) foram registradas pela primeira vez no estado de Santa Catarina e, com exceção de Z. bilineata, também no sul do Brasil. Além destas espécies, também foram coletadas Zygothrica hypandriata Burla 1956, Z. orbitalis (Sturtevant 1916) (como Z. parilis), Z. prodispar Duda 1925 e Z. vittimaculosa Burla 1956. Com exceção de Z. bilineata e Z. hypandriata, estes registros representam os novos limites de distribuição geográfica sul para estas espécies. Todas as espécies coletadas foram representadas por poucos 
indivíduos, provavelmente como conseqüência do método de coleta, e a maioria delas foi capturada em invernos e primaveras. Cinco espécies foram restritas ao local estudado mais preservado e a maioria dos indivíduos foi coletada em áreas de floresta. Entretanto, quatro espécies também foram capturadas em ambientes urbanos ou xéricos, indicando uma tolerância mais alta e uma versatilidade ecológica mais ampla do que previamente era pensado para este gênero, pelo menos para algumas de suas espécies.

Palavras-chave: Neotrópico, novos registros, distribuição de espécies.

\section{Introduction}

The type species of the genus Zygothrica, Z. dispar, was initially described as a subgenus in Achias (Platystomatidae) in 1830 by Wiedemann. The use of Zygothrica as a generic name began with Loew (1873). Sturtevant (1920) described several species and was one of the first authors to emphasize the study of this genus. Later, Duda (1925), working with specimens collected in Costa Rica, and Burla (1956), with specimens collected in Brazil, described a large number of species. These authors greatly promoted the study of this genus, as well as the revision and species descriptions done by Grimaldi (1987, 1990). Up to now, the genus includes 123 described species (Bächli 2006), most of them restricted to the Neotropics, where the genus originated, while few species were registered in other areas of the Earth (Grimaldi 1990).

The genus Zygothrica assembles species predominantly mycophagous (Malogolowkin 1952, Grimaldi 1987, 1990) and some flower-feeding species (Grimaldi 1987). However, most studies focusing on drosophilids use banana baits to attract the flies, since this strategy is very efficiently draws a considerable number of species, mainly Drosophila. Probably, this is the reason why Zygothrica species were not sampled or their abundances were so low that, in general, these flies were not identified to a specific level or were even neglected in most studies. This fact makes the ecology and biogeography of the genus Zygothrica poorly known.

The present paper extends the knowledge on the distribution of ten species of the genus Zygothrica and registers the southernmost occurrences so far observed for eight of them. Besides, ecological aspects are also briefly discussed.

\section{Material and Methods}

Forested, coastal and urban areas in the State of Santa Catarina (Table 1), southern Brazil, were sampled during about four years (Table 2).

Collections were conducted using traps made according to the Tidon \& Sene (1988) designs but with some modifications. Fly identification was based on external morphology and mainly on the shape of male terminalia (males dissected according to Wheeler \& Kambysellis 1966). Voucher specimens of the species collected are preserved in microvials (in ethanol $70^{\circ}$ ) or pinned. These specimens were deposited in reference collections at the Universidade Federal de Santa Catarina and Universidade Federal do Rio Grande do Sul.

\section{Results}

More than 315.000 drosophilids were collected among the nine sampled sites during this four-year study, but only 137 specimens were assigned to Zygothrica. Among the 73 specimens of this genus identified (at the species level), 33 belonged to only one species, Z. orbitalis (Sturtevant 1916) (as Z. parilis), and the remaining individuals were assigned to nine other species. Six of these species were registered for the first time in the State of Santa Catarina (Table 3) and among these, only Z. bilineata (Williston 1896) had previously been registered anywhere else in southern Brazil (Grimaldi 1990). Zygothrica hypandriata Burla 1956, Z. orbitalis (as Z. parilis) and Z. vittimaculosa Burla 1956 have occurrences registered in Santa Catarina referred by Val \& Kaneshiro (1988) while the record of Zygothrica prodispar Duda 1925 in this state was referred by Grimaldi (1987).

\section{Discussion}

Zygothrica apopoeyi Burla 1956 and Z. lanceolata Burla 1956 were previously recorded just in Brazil (Burla 1956, Val \& Kaneshiro 1988). Zygothrica nigropleura Grimaldi 1987 is only known from its type locality, in Brazil (Grimaldi 1987). These species were recorded in the southeastern area and, therefore, our data set represents the first record in southern Brazil for them.

In the same way, Z. hypandriata and Z. vittimaculosa were previously recorded only in Brazil, but these records occurred both in the southern and southeastern areas (Burla 1956, Val \& Kaneshiro 1988).

Table 1. Collection sites, co-ordinates, and their respective environment types and preservation levels.

Tabela 1. Locais de coleta, coordenadas geográficas e seus respectivos tipos de ambiente e graus de preservação.

\begin{tabular}{|c|c|c|c|}
\hline Sampled site & Co-ordinates & Environment & Preservation Level \\
\hline A - Piraí* & $26^{\circ} 17^{\prime} 15^{\prime \prime} \mathrm{S}$ and $49^{\circ} 00^{\prime} 56^{\prime \prime} \mathrm{W}$ & Rain Forest & a \\
\hline B - Unidade de Conservação Ambiental Desterro & $27^{\circ} 31^{\prime} 26^{\prime \prime} \mathrm{S}$ and $48^{\circ} 30^{\prime} 32^{\prime \prime} \mathrm{W}$ & Rain Forest & $\mathrm{b}$ \\
\hline C - Morro da Lagoa da Conceição & $27^{\circ} 35^{\prime} 27^{\prime \prime} \mathrm{S}$ and $48^{\circ} 28^{\prime} 33^{\prime \prime} \mathrm{W}$ & Rain Forest & $\mathrm{c}$ \\
\hline D - Morro da Cruz & $27^{\circ} 35^{\prime} 04^{\prime \prime} \mathrm{S}$ and $48^{\circ} 31^{\prime} 04^{\prime \prime} \mathrm{W}$ & Rain Forest & $\mathrm{d}$ \\
\hline E - Manguezal do Itacorubi & $27^{\circ} 34^{\prime} 14^{\prime \prime} \mathrm{S}$ and $48^{\circ} 30^{\prime} 33^{\prime \prime} \mathrm{W}$ & Mangrove Forest & $\mathrm{e}$ \\
\hline F - Manguezal do Rio Tavares & $27^{\circ} 39^{\prime} 13^{\prime \prime} \mathrm{S}$ and $48^{\circ} 32^{\prime} 12^{\prime \prime} \mathrm{W}$ & Mangrove Forest & $\mathrm{f}$ \\
\hline G - Restinga do Rio Tavares & $27^{\circ} 38^{\prime} 21^{\prime \prime} \mathrm{S}$ and $48^{\circ} 27^{\prime} 49^{\prime \prime} \mathrm{W}$ & Strand Forest & $\mathrm{g}$ \\
\hline H - Campus Universitário UFSC & $27^{\circ} 36^{\prime} 13^{\prime \prime} \mathrm{S}$ and $48^{\circ} 31^{\prime} 22^{\prime \prime} \mathrm{W}$ & Urban & $\mathrm{h}$ \\
\hline I - Brigada Motorizada do Exército & $27^{\circ} 35^{\prime} 27^{\prime \prime} \mathrm{S}$ and $48^{\circ} 33^{\prime} 02^{\prime \prime} \mathrm{W}$ & Urban & $\mathrm{h}$ \\
\hline
\end{tabular}

*This is the only continental site, the others are insular ones. a) Well-preserved area, in advanced condition of regeneration, with very low human influence; b) Well-preserved area, in advanced condition of regeneration, with low human influence; c) Moderately preserved area, in advanced condition of regeneration, with moderate human influence; d) Area at an intermediary level of regeneration, with high human influence; e) Mangrove vegetation with high human influence; f) mangrove vegetation with low human influence; g) Strand (or "restinga") vegetation area with high human influence; and h) Cultivated vegetation area with high human influence. 
Table 2. Sampling periods for each collection site.

Tabela 2. Períodos de amostragem em cada local de coleta.

\begin{tabular}{lll}
\hline Season/Year & \multicolumn{1}{c}{ Period } & \multicolumn{1}{c}{ Sampled sites* } \\
\hline Spring/2001 & 09 Oct. & A \\
Summer/2002 & 22 Jan. & A \\
Autumn/2002 & 19 May - 26 May & A, G \\
Winter/2002 & 21 Jul. - 07 Sep. & A, B, C, D, E, G, H, I \\
Spring/2002 & 07 Oct. - 22 Nov. & A, B, C, D, E, G, H, I \\
Summer/2003 & 17 Jan. - 11 Mar. & A, B, C, D, E, G, H, I \\
Autumn/2003 & 23 Apr. - 30 May & A, B, C, D, E, G, H, I \\
Winter/2003 & 21 Jul. - 29 Aug. & A, B, C, D, E, G, H, I \\
Spring/2003 & 21 Oct. - 02 Dec. & A, E, F, G \\
Summer/2004 & 20 Jan. - 24 Feb. & A, E, F, G \\
Autumn/2004 & 14 Apr. - 22 May & A, E, F, G \\
Winter/2004 & 23 Jul. - 09 Aug. & A, E, F \\
Spring/2004 & 26 Oct. - 04 Nov. & A, E, F \\
Summer/2005 & 24 Jan. - 28 Feb. & A, E, F \\
Autumn/2005 & 18 Apr. - 22 Apr. & E, F \\
Winter/2005 & 26 Jul. - 30 Jul. & E, F \\
\hline
\end{tabular}

* Sampled sites according to Table 1.

Table 3. Temporal and spatial occurrence of species of the genus Zygothrica recorded in the state of Santa Catarina.

Tabela 3. Ocorrência temporal e espacial das espécies do gênero Zygothrica registradas no estado de Santa Catarina.

\begin{tabular}{|c|c|}
\hline Species & $\begin{array}{c}\text { Season/Year, Site, and Absolute } \\
\text { Abundance }\end{array}$ \\
\hline Z. apopoeyi ${ }^{1}$ Burla, 1956 & wi03 - A(1); sp04 - A(1) \\
\hline Z. bilineata ${ }^{2}$ (Williston, 1896) & $\begin{array}{c}\text { wi02 - B(1); au03 - D(1); } \\
\text { su05 - A(3) }\end{array}$ \\
\hline Z. dispar ${ }^{1}$ (Wiedemann, 1830) & au03 - A (1), D(6); wi05 - F(3) \\
\hline Z. hypandriata Burla, 1956 & sp04 - A(2) \\
\hline Z. lanceolata ${ }^{1}$ Burla, 1956 & $\mathrm{au} 03-\mathrm{A}(2)$ \\
\hline Z. nigropleura ${ }^{1}$ Grimaldi, 1987 & $\mathrm{au} 03-\mathrm{A}(1)$ \\
\hline Z. orbitalis (Sturtevant, 1916) & $\begin{array}{c}\text { wi02 - E(1), G(8), H(1); sp02 } \\
\text { - D(1), I(1); au03 - C(3), D(1), } \\
\mathrm{G}(1), \mathrm{H}(6) ; \text { wi03 - B(2); sp03 } \\
\text { - E(1); wi04 - A(5), F(1); } \\
\text { wi05 - E(1) }\end{array}$ \\
\hline Z. poeyi ${ }^{1}$ (Sturtevant, 1921) & $\begin{array}{c}\text { wi02 - A(2); sp03 - A(1); } \\
\text { sp04 - A(1) }\end{array}$ \\
\hline Z. prodispar Duda, 1925 & au03 - D(2); au05 - F(1) \\
\hline Z. vittimaculosa Burla, 1956 & $\begin{array}{c}\text { sp01 - A (1); wi02 - E(3), H(1); } \\
\text { sp02 - D(1); su03 - I(2); au03 } \\
\text { - A(1), D(1); sp03 - A(1) }\end{array}$ \\
\hline
\end{tabular}

The lower-case letters represent the seasons (wi - Winter, sp - Spring, su - Summer, au - Autumn); the numbers following represent the year (p.ex., 01 - 2001, 02 - 2002); the upper-case letters represent the sites (according to Table 1) and the numbers between brackets stand for the absolute abundance at each collection site. First records in: ${ }^{1}$ southern Brazil and ${ }^{2}$ state of Santa Catarina.
On the other hand, Z. orbitalis were collected in northern Brazil, as Z. ochracella (Frota-Pessoa 1951, Bächli 1988), southeastern, as Z. parilis (Burla 1956, Val \& Kaneshiro 1988) and Z. nitidifrons (Burla 1954), and southern regions of the country, as Z. parilis (Val $\&$ Kaneshiro 1988). This species were also collected in Panama (Grimaldi 1987) and Peru (as Z. nitidifrons Duda 1927).

Zygothrica bilineta specimens have been collected from southern South America (southernmost state of Brazil, Rio Grande do Sul) to northern Central America. According to Grimaldi (1990), this species spreads over Bolivia, Brazil, Colombia, Peru, and several countries of Central America. This species and Z. hypandriata were the only ones collected by us to present previous records more to the south than the record made in our study.

Zygothrica dispar, Z. poeyi and Z. prodispar present a wide geographical distribution. The first of these, whose geographical distribution ranges from Mexico to Brazil (Burla 1956, Grimaldi 1987, Val \& Kaneshiro 1988, and others), had not been collected in southern Brazil before. Zygothrica poeyi, predominantly recorded in Central America (Duda 1925, Patterson \& Mainland 1944, Heed 1957) but also in Peru (Duda 1927) and Brazil (Burla 1956), had never been registered in southern Brazil either. Zygothrica prodispar, which spreads from southern North America to southern Brazil (Grimaldi 1987), had already been recorded in the State of Santa Catarina (Grimaldi 1987 ) but more to the north $\left(27^{\circ} 11^{\prime} \mathrm{S}\right)$ than in the present study.

According to Val \& Kaneshiro (1988), Zygothrica parapoeyi Burla 1956, Z. parvipoeyi Burla 1956, Z. ptialialis Burla 1956, Z. subcandens Burla 1956, and Z. vittisecta Burla 1956 were also recorded in the state of Santa Catarina. So, up to now, there are 15 species registered for this area in Brazil.

All the collected species of Zygothrica were recorded at such a little number of individuals that their records might be considered casual. This small number of specimens, however, may not reflect the true size of the population, but may be a consequence of the collection method, since species of Zygothrica are predominantly mycophagous (Malogolowkin 1952, Grimaldi 1987, 1990).

Fifty-seven individuals $(78 \%)$ were captured in winters and springs, suggesting that there might be a biotic or abiotic factor influencing the number of flies factually captured, such as shortage of food or the existence of stressful environment. Tidon (2006) suggested that this last factor might favor migrations of drosophilids, which may increase the capture of flies. Wheeler (1952), in a study that investigated the mycophagous genus Leucophenga (Diptera, Drosophilidae), stated that "in times of severe drought, when it may be assumed that the usual feeding sources are absent or nearly so, these flies will come to banana-baited traps fairly readily". If this statement is valid to Zygothrica, it could explain the temporal distribution observed in our data set.

The species of Zygothrica are forest-dwelling species, and are usually considered sensitive to wide fluctuations in abiotic factors (Parsons 1991). Indeed, five species were restricted to site A, the most well-preserved studied site, and most individuals have been collected in forests. Nevertheless, it is important to highlight that four species were also captured within urban or xeric environments, which may indicate a higher tolerance and a wider ecological versatility, as opposed to what has previously been thought, at least for some species. Among these, Z. dispar and Z. prodispar were collected in mangrove forests; $Z$. vittimaculosa was captured in the strand forest, in a mangrove forest and in the urban environment; and Z. orbitalis was observed in all collection sites. Therefore, these results reinforce the idea that the knowledge on the species of this genus needs to be further increased. 
Although a suitable collection method for the study of Zygothrica has not been used, our data set improves the knowledge on the geographical distribution of ten species of this genus and provides new insights on the ecology of this genus. This observation provides important support for the knowledge on the diversity in the Atlantic Rain Forest, one of the more speciose hotspots in the world (Myers et al. 2000).

\section{Acknowledgments}

This study was partly supported by the Brazilian Agencies CAPES and CNPq. Thanks are due to Dra. Francisca C. do Val, from Universidade de São Paulo, who elucidated us some distributional aspects of a couple of species.

\section{References}

BÄCHLI, G. 1988. Die Drosophiliden-Arten (Diptera) in der Sammlung des Naturhistorischen Museums Wien. Annln naturh. Mus. Wien 90:131-148. http://www.dgrc.kit.ac.jp/ jdd/class/0709/03070918.pdf

BÄCHLI, G. 2006. Taxodros, the database on taxonomy of Drosophilidae. Available from: http://www.taxodros.unizh.ch/. (Accessed on December, 2006).

BURLA, H. 1954. Study on the polymorphism in Zygothrica dispar and Z. prodispar, and description of Z. laticeps sp. n. (Drosophilidae, Diptera). Archos Mus. parana. 10:231-252. http://www.dgrc.kit.ac.jp/ jdd/ class/0703/03070371.pdf

BURLA, H. 1956. Die Drosophilidengattung Zygothrica und ihre Beziehung zur Drosophila-Untergattung Hirtodrosophila. Mitt. Zool. Mus. Berl. 32:189-321. http://www.dgrc.kit.ac.jp/ jdd/class/0709/03070926.pdf

DUDA, O. 1925. Die costaricanischen Drosophiliden des Ungarischen National-Museums zu Budapest. Ann. Hist-Nat. Mus. Natl. Hung. 22:149-229. http://www.dgrc.kit.ac.jp/ jdd/class/0708/03070883.pdf

DUDA, O. 1927. Die sudamerikanischen Drosophiliden (Dipteren) unter Berucksichtigung auch der anderen neotropischen sowie der nearktischen Arten. Arch. Naturgesch. 91(11):1-228.

FROTA-PESSOA, O. 1951. Drosophila (Hirtodrosophila) magnarcus“"n. sp. (Diptera, Drosophilidae). Rev. Bras. Biol. 11:407-411. http://www.dgrc. kit.ac.jp/ jdd/class/0703/03070374.pdf

GRIMALDI, D.A. 1987. Phylogenetics and taxonomy of Zygothrica (Diptera: Drosophilidae). Bull. Am. Mus. Nat. Hist. 186:103-268. http://www.dgrc. kit.ac.jp/ jdd/class/0709/03070932.pdf
GRIMALDI, D.A. 1990. Revision of Zygothrica (Diptera: Drosophilidae), Part II. The First African Species, Two New Indo-Pacific Groups, and the bilineata and samoaensis Species Groups. Am. Mus. Novit. 2964:1-31. http://www.dgrc.kit.ac.jp/ jdd/class/0709/03070933.pdf

HEED, W.B. 1957. Ecological and distributional notes on the Drosophilidae (Diptera) of El Salvador. Univ. Texas Publs 5721:62-78.

LOEW, H. 1873. Diptera nova, in Pannonia inferiori et in confinibus Daciae regionibus a Ferd. Kowarzio capta. Dtsch. ent. Z. 17:33-52.

MALOGOLOWKIN, C. 1952. Notas sobre "Zygothrica dispar" (Diptera, Drosophilidae). Rev. Bras. Biol. 12 (4):455-457. http://www.dgrc.kit. ac.jp/ jdd/class/0704/03070414.pdf

MYERS, N., MITTERMEIER, R.A., MITTERMEIER, C.G., FONSECA, G.A.B. \& KENT, J. 2000. Biodiversity hotspots for conservation priorities. Nature 403:853-858. http://www.nature.com/nature/journal/v403/ n6772/abs/403853a0.html

PARSONS, P.A. 1991. Biodiversity conservation under global climatic change: the insect Drosophila as a biological indicator? Global Ecol. Biogeog. Lett. 1:77-83.

PATTERSON, J.T. \& MAINLAND, G.B. 1944. The Drosophilidae of Mexico. Univ. Texas Publs 4445:9-101.

STURTEVANT, A.H. 1920. The dipterous genus Zygothrica of Wiedemann. Proc. U. S. Natl. Mus. 58:155-158. http://www.dgrc.kit.ac.jp/ jdd/ class/0704/03070430.pdf

TIDON, R. 2006. Relationships between drosophilids (Diptera, Drosophilidae) and the environment in two contrasting tropical vegetations. Biol. J. Linn. Soc. 87:233-247. http://www.blackwell-synergy.com/doi/pdf/10.1111/ j.1095-8312.2006.00570.x

TIDON, R. \& SENE, F.M. 1988. A trap that retains and keeps Drosophila alive. D.I.S. 672:89.

VAL, F.C. \& KANESHIRO, K.Y. 1988. Drosophilidae (Diptera) from the Estacao Biologica de Boraceia, on the coastal range of the State of Sao Paulo, Brazil: Geographical distribution, In Proceedings of a Workshop on Neotropical Distribution Patterns (W.R. Heyer \& P.E. Vanzolini, eds). Academia Brasileira de Ciências, Rio de Janeiro, p.189-203

WHEELER, M.R. 1952. Drosophilidae of the Nearctic region, exclusive of the genus Drosophila. Univ. Texas Publs 5204:162-218. http://www.dgrc. kit.ac.jp/ jdd/class/0706/03070682.pdf

WHEELER, M.R. \& KAMBYSELLIS, M.P. 1966. Notes on the Drosophilidae (Diptera) of Samoa. Univ. Texas Publs 6615:533-565.

WIEDEMANN, C.R.G. 1830. Achias Dipterorum genus a Fabricio conditum; illustratum novisque auctum et conventui physicorum germanorum oblatum. Mohr, Kiliae. 